\title{
Slik kan sykepleiere oppdage sepsis tidligere
}

Sykepleiere er i en nøkkelposisjon til å oppdage sepsis tidlig. Men de trenger mer kunnskap og bedre klinisk kompetanse, og de må kjenne til kartleggingsverktøyene.

\section{Forfattere}

Eirin Aspsæther

Sykepleier

Avdeling E, Sunndal helsetun

Vilde Birkestøl Lien

Sykepleier

Medisinsk avdeling post 1, Ålesund sjukehus

Sven Inge Molnes

Førstelektor

Institutt for helsevitenskap, Norges teknisk-naturvitenskapelige universitet, Ålesund

sepsis Kompetanse Litteraturstudie Sykepleie

Sykepleien 2019 107(76029)(e-76029)

DOI: https://doi.org/10.4220/Sykepleiens.2019.76029

\section{Hovedbudskap}

Sykepleieren spiller en viktig rolle i å identifisere tidlige symptomer på sepsis og kartlegge pasienter som står i fare for å utvikle tilstanden. Men mange sykepleiere mangler kunnskaper. For å identifisere sepsis tidligere må kunnskapen økes gjennom undervisning, simulering og klare retningslinjer. I tillegg må kartleggingsverktøy tas i bruk. 
I Norge er det omtrent 7000 tilfeller av sepsis årlig (1).

Statistikker viser at 19 millioner mennesker rammes av sepsis hvert år. Fem millioner dør på verdensbasis som følge av tilstanden (2). Flere av dem som overlever sepsis, får langvarige fysiske, psykiske og kognitive funksjonshemninger (3).

I 2016 kom en ny, internasjonal definisjon av sepsis, som vektla behovet for mer oppmerksomhet, slik at diagnosen kan avdekkes på et tidligere tidspunkt (3) (se faktaboks). Diagnosen er i dag et økende problem. Årsakene kan være at befolkningen blir eldre, og at behandlingene mot sykdommer har blitt mer aggressive og intensive. Vi ser dessuten en økende mikrobiell resistens (1).

\section{Sepsis}

Også kalt blodforgiftning. Sepsis er livstruende organsvikt utløst av sannsynlig eller påvist infeksjon.

Kilde: Store medisinske leksikon

\section{Hensikten med studien}

Hensikten er å belyse sykepleierens rolle med å identifisere sepsis hos pasienter på sengepost.

Ved å observere pasienten kan sykepleieren få nyttig informasjon om pasienten og pasientens helsetilstand. Når sykepleieren oppfatter hvilke pasienter som står i fare for å utvikle sepsis og observerer og kartlegger dem nøye, kan hun eller han bidra til å forebygge komplikasjoner og bedre prognosen for pasienten (4).

\section{三 «I Norge er det omtrent 7000 tilfeller av sepsis årlig.»}

\section{Metode}


Studien er en systematisk litteraturstudie basert på åtte kvantitative forskningsartikler. Vi gjennomførte søk i databasene CINAHL, PubMed og Ovid MEDLINE fra oktober til desember 2017 med følgende inklusjonskriterier: engelsk- og skandinaviskspråklige artikler publisert i tidsrommet 2012-2017, som var overførbare til det norske helsevesenet.

Vi benyttet PIO-skjema siden dette skjemaet bidrar til struktur og klargjør spørsmålet for systematisk litteratursøk, utvelgelse og kritisk vurdering av litteraturen (se faktaboks). Vi valgte å utelukke C (Comparison) fra PICO-skjemaet, da vi ikke ønsket å sammenlikne med et annet tiltak.

\section{PICO}

PICO er et verktøy som hjelper med å gjøre spørsmålet (problemstillingen) tydelig og presist i kunnskapsbasert praksis. Etter at du har formulert et presist spørsmål, bør du bestemme hvilket kjernespørsmål du står overfor. Dette hjelper deg når du skal søke etter forskning om spørsmålet.

PICO er en forkortelse for elementer som ofte vil være med i et spørsmål:

$\mathrm{P}=$ Patient/problem

$\mathrm{I}=$ Intervention

$\mathrm{C}=$ Comparison

$\mathrm{O}=$ Outcome

Kilde: kunnskapsbasertpraksis.no

\section{Analyse}

Vi gjennomførte analysen etter Evans' (5) modell, som består av fire trinn: 
- Samle inn datamateriale.

- Identifisere nøkkelfunn i hver studie. Vi leste gjennom én og én artikkel hver for oss og skrev ned alle nøkkelfunn underveis.

- Sammenlikne ulikheter og likheter, identifisere forskjeller mellom studiene og finne felles temaer.

- Beskrive fenomenet, der kategoriene og temaene blir utgangspunkt for hovedtemaet. Dette trinnet resulterte i tre hovedtemaer (tabell 1).

Tabell 1. Hovedtemaer og kategorier

\begin{tabular}{ll}
\hline & \\
Hovedtema & Kategorier \\
Hvordan kan kunnskapsnivå og klinisk & Tydelige retningslinjer \\
kompetanse utvikles? & $\varnothing$ kt bevissthet om sepsis \\
& Undervisning \\
& Praktisk trening og simulering \\
& Forbedring av rutiner \\
& Fornyelse av kunnskap \\
\hline Sykepleierens ansvar på sengepost & Nøkkelposisjon \\
& Individuelt ansvar $\rightarrow$ faglig oppdatert \\
\hline Verktøy som hjelpemiddel & Ta i bruk eksisterende retningslinjer/rutiner \\
ved kartlegging & Bør være enkelt å bruke \\
& For sen diagnostisering \\
& Lite spesifikke \\
\hline
\end{tabular}

\section{Tidligere studier}

Flere av studiene påpekte at sykepleieren er i en nøkkelposisjon til å kunne identifisere sepsis fordi sykepleieren står nærmest pasienten og observerer pasienten døgnet rundt (6-8).

Videre kom det frem at sykepleiere har behov for mer kunnskap om temaet siden sykepleiere spiller en sentral rolle med å identifisere sepsis (9-10). Flere av studiene implementerte egne kartleggingsskjemaer for sepsis, noe som resulterte i tidlig identifisering av tilstanden, kortere liggetid og redusert mortalitet (7-9, 11).

Delaney og medarbeidere (6) fremhevet hvor viktig det var at sykepleiere holder seg faglig oppdatert, og at de benytter seg av undervisningsmuligheter for å forbedre kompetansen og kunnskapen. 
Et viktig funn i flere studier var at mange sykepleiere følte de hadde behov for mer kunnskap om sepsis da de kjente på et ansvar for å bidra til tidlig identifisering (9-10, 12). Systematisk kartlegging av sykepleierens rolle med å identifisere sepsis kan gi bedre prognose for pasientene $(6-7,11)$.

\section{Øke klinisk kompetanse}

Flere av studiene er oppmerksomme på ulike læringsmetoder for hvordan kunnskapsnivået og den kliniske kompetansen kan økes $(6-8,10)$. Forfatterne nevner praktisk og teoretisk undervisning, innføring i bruk av kartleggingsverktøy og klare retningslinjer. Undervisningen burde være tilpasset sykepleiere, noe som kan sette sykepleieren i en bedre posisjon til å identifisere sepsis på et tidlig tidspunkt.

Noen undersøkte hvilke forbedringer man så av sykepleierens kunnskaper før og etter at teoretisk undervisning ble gitt (6-8). Det kom frem at sykepleierne følte seg tryggere på å identifisere sepsis etter et undervisningsprogram som innebar både teoretisk undervisning og simulering (6). Et viktig funn er at mange sykepleiere mangler nødvendig kunnskap og kompetanse til å gjenkjenne sepsis (7).

Torsvik og medarbeidere (7) implementerte et egendefinert skjema som beskrev hvordan sykepleiere skulle gå frem ved mistanke om sepsis. Innføringen av skjemaet førte til større bevissthet blant sykepleierne, og de fattet raskere mistanke om sepsis. Bruk av skjemaet resulterte i raskere behandling, reduksjon i utvikling av tilstanden og økt overlevelse på over 40 prosent.

\section{Ansvaret på sengepost}


Sykepleieren på sengepost er ansvarlig for å ha nødvendig kunnskap og kompetanse til å kunne gjenkjenne og identifisere sepsis $(6,7)$. Fordi sykepleierne er i en god posisjon til å identifisere sepsis bør de få mer ansvar (6, 8-9). Tromp og medarbeidere (8) ønsket å belyse sykepleierens viktige ansvar i et sepsisforløp og fant at jo større ansvar sykepleieren hadde med å identifisere sepsis, desto mer bidro det til økt tverrfaglighet og dermed bedre ivaretakelse av pasienten og pasientens behov.

\section{三 «Fordi sykepleierne er i en god posisjon til å identifisere sepsis, bør de få mer ansvar.»}

Det er et sykepleieransvar å gi god pleie og omsorg til komplekse pasienter med sammensatte behov og inneha kunnskapen som trengs for å kunne gjenkjenne og reagere på tegn til akutt og kritisk sykdom (6). Sykepleiere er de første til å vurdere pasientens helsetilstand og har dermed både mulighet til og ansvar for å mistenke sepsis og ta initiativ til at behandling iverksettes raskt (9).

\section{Verktøy til kartlegging}

Når sykepleiere brukte kartleggingsverktøy, ble pasienter tidligere identifisert enn når verktøyet ikke ble benyttet. I tillegg var kvaliteten på sykepleien bedre ved bruk av kartleggingsverktøy (8). Dersom kartleggingsverktøy skal være nyttig, er det viktig at sykepleierne har nødvendig kunnskap om sepsis (7).

Nesten halvparten av alle pasientene på sengepost oppfylte minst to eller flere SIRS-kriterier (systemisk inflammatorisk responssyndrom) i løpet av sykehusoppholdet (12-13). qSOFA (Quick Sequential Organ Failure Assessment) er ikke det kartleggingsverktøyet som foretrekkes på sengepost eller på intensivavdelinger (12), selv om det har vist seg å være mer nøyaktig enn SIRS. NEWS (National Early Warning Score) er det mest presise kartleggingsverktøyet på sengepost (12). 
Flere av sykepleierne var ukjente med SIRS-kriteriene, og hele 85 prosent svarte at de var litt kjent med eller ikke kjent i det hele tatt med SIRS. Et annet relevant funn viste at sykepleierne hadde liten tiltro til egen kunnskap og lente seg mye på kartleggingsverktøyene (13).

I noen studier ble det utarbeidet egne kartleggingsverktøy med utgangspunkt i allerede eksisterende verktøy. I arbeidet benyttet de elementer fra forskjellige kartleggingsverktøy og fra Surviving Sepsis-kampanjen, siden mange opplevde noen verktøy som upresise og ufullstendige (7-9). Mortaliteten ved sepsis er høyere blant pasienter på sengepost enn på intensivavdeling $(11,13)$.

\section{Hvordan bedre kunnskapen?}

Vår studie viser tydelig hvor viktig det er for sykepleierne å holde seg oppdatert, ta ansvar og benytte seg av undervisningsmuligheter for å forbedre kompetansen og kunnskapene. Kompetanse innebærer å være kvalifisert til å kunne ta beslutninger og handle innenfor et bestemt funksjonsområde (14).

Det viste seg at sykepleiere som tidligere hadde erfaring med sepsispasienter, hadde mer kunnskap om sepsis og følte seg tryggere på identifiseringen (10). Nyutdannede og yngre sykepleiere hadde mer kunnskap om sepsis. Sykepleierne som var over 50 år, skåret lavere på kunnskap om sepsis. Årsaken kan være at SIRS-kriteriene først ble introdusert i 1992 (6, 9-10).

\section{三 «Nyutdannede og yngre sykepleiere hadde mer kunnskap om sepsis.»}


Nortvedt og Grønseth (4) påpeker derimot at erfarne sykepleiere har solid kunnskap etter flere år i praksis. Videre belyser de hvor nødvendig det er for sykepleiere å holde seg oppdatert på ny forskningslitteratur, og de understreker at sykepleie skal baseres på oppdatert og forskningsbasert kunnskap.

Sykepleieren har en fagutviklende funksjon som innebærer å bidra til kontinuerlig kvalitetsforbedring og holde seg faglig oppdatert. Sykepleieren kan ha nytte av å simulere realistiske pasientsituasjoner for å utvikle observasjonsevnen. Ifølge Delaney og medarbeidere får sykepleierne bedre kunnskap om sepsis hvis de har simulering sammen med teoretisk undervisning (6).

\section{Foreslåtte tiltak}

Sykepleierne foreslo selv tiltak for å bedre behandlingen av sepsispasienter, og de foreslo tiltak for å øke kunnskapsnivået i sin egen yrkesgruppe. Sykepleierne tok blant annet i bruk et enkelt, effektivt og standardisert kartleggingsverktøy for å kunne identifisere sepsis tidlig. Sykepleiere som hadde ansvar for pasienter med sepsis eller pasienter som sto i fare for å utvikle sepsis, ble fritatt for andre oppgaver for å kunne følge opp pasienten tettere (9).

Imidlertid var det sykepleiere på akuttmottak som foreslo å ta i bruk kartleggingsverktøy. Dermed kan det diskuteres hvorvidt tiltakene vil være nyttige for sykepleiere på sengepost. Mange sykepleiere lente seg mye på kartleggingsverktøy (12), noe vi tolker som at de var usikre på sin egen kunnskap i møte med risikopasienter.

Når sykepleieren observerer pasienten, brukes sansene til å hente inn data. Sykepleierens evne til å observere betegnes som «det kliniske blikket». Evnen til klinisk blikk og sanselig forståelse utvikles ved å observere. 
Det er derfor viktig at sykepleieren har kunnskap om og forståelse for hvilke observasjoner som bør gjøres (14): observasjon av pasientens respirasjon, sirkulasjon, hud, bevissthetsgrad og eliminasjon er viktig ved sepsis eller mistanke om sepsis (15). Tidlig identifisering og målrettet behandling reduserer både mortaliteten og kostnader knyttet til behandling av sepsis $(11,13)$.

\section{Nøkkelposisjon}

Lovverk og yrkesetiske retningslinjer for sykepleiere, som for eksempel helsepersonelloven, ICN (International Council of Nurses) og rammeplanen for sykepleierutdanningen, skal belyse ansvaret for at egen praksis er etisk, faglig og juridisk forsvarlig, noe som vil påvirke kvaliteten på sykepleien (4).

Sykepleiere må ta ansvar for egen læring og holde seg oppdatert på forskning innen sitt fagområde for å bidra til at ny kunnskap anvendes i praksis. Videre kan sykepleieren forbedre og utvikle sin kliniske kompetanse gjennom hele yrkeslivet $(4,6)$. Funn viser at mange pasienter diagnostiseres for sent (10), og at sykepleieren står i en god posisjon til å observere tidlige tegn på sepsis.

Flere beskriver at sykepleierne er i en nøkkelposisjon fordi de ser pasienten ofte og gjennom hele døgnet (68). Denne gode posisjonen til å kunne identifisere sepsis bør gi sykepleierne mer ansvar, noe som kan bidra til at de identifiserer tilstanden på et tidligere tidspunkt $(6,8)$.

Helsepersonelloven $\S 4$ legger vekt på forsvarlighet i utøvelsen av sykepleie. Den slår fast at man skal utføre arbeidet i samsvar med kravene til omsorgsfull pleie og faglig forsvarlighet, som kan forventes ut fra kvalifikasjoner, karakter og situasjon (16). 
Sykepleierne erfarte at det var for få folk på jobb, for lite medisinsk utstyr og for stor arbeidsmengde til at de kunne yte forsvarlig sykepleie (9). Arbeidsforholdene er i strid med kravet om forsvarlighet i yrkesutøvelsen, og vi tror mangel på ressurser kan føre til utfordringer med å kartlegge sepsis systematisk.

\section{Sykepleierens ansvar}

Sykepleieren på sengepost har et ansvar for å ivareta pasientens grunnleggende behov. Sykepleieren bør snakke med pasienten om hva som er viktig for ham eller henne, og om hvordan pasientens behov kan tilfredsstilles (17).

For en akutt syk pasient er det normalt å oppleve angst og utrygghet i forbindelse med situasjonen vedkommende er i (15). Undersøkelser og behandling, ubehagelige prosedyrer og følelsen av hjelpeløshet samt det å miste kontroll over egen situasjon kan være årsaker til at pasienten får denne opplevelsen.

I situasjoner der en pasient er kritisk syk, kan pasientens autonomi og integritet bli truet som følge av at det kan være lett å behandle pasienten som et objekt (15). Det er derfor viktig at sykepleieren på sengepost ivaretar psykiske behov så vel som somatiske. Som sykepleier har vi et ansvar for å ivareta omsorgen til den komplekse pasienten (6).

\section{Godt hjelpemiddel}

Kartleggingsverktøy kan være et godt hjelpemiddel til å oppdage tegn på infeksjon og endring i pasientens helsetilstand for helsepersonell som ikke føler seg trygge på sin egen kliniske vurdering. Videre kan kartleggingsverktøy også bidra til bedre beslutninger enn ved bruk av faglig skjønn, og sykepleieren kan få større tiltro til sin egen evne til å identifisere sepsis (4). 
Tromp og medarbeidere fant at kvaliteten på sykepleien ble forbedret, og at pasienter ble tidligere identifisert når kartleggingsverktøy ble benyttet (8). Det er viktig å anvende kartleggingsverktøy på korrekt måte for ikke å svekke kartleggingsverktøyets nytteverdi. Vi tror det kan øke kvaliteten på sykepleien og bidra til tidlig identifisering av sepsis når verktøy brukes.

Andre funn viser at sykepleiere lente seg på kartleggingsverktøyene og hadde liten tiltro til egen kunnskap (12). Det kan anses både som en styrke og en svakhet fordi det kan bidra til at kartleggingsverktøy blir brukt, men også til at sykepleierne glemmer det kliniske blikket og egne observasjoner. Vi tror det vil være viktig at sykepleiere ikke anvender kartleggingsverktøy alene, men i kombinasjon med egne kunnskaper, faglig skjønn og det kliniske blikket.

\section{Må bruke tydelig språk}

Observasjoner av vitale tegn og kartlegging av organfunksjon ble i liten grad utført på sengepost. Feiltolkning, utilstrekkelige målinger og forsinket reaksjon var blant årsakene som førte til at tilstanden sent ble identifisert.

Sykepleiere har en tendens til å være diffuse i språket, noe som kan føre til utfordringer i samhandling med andre profesjoner (7), viser en studie til Torsvik og medarbeidere. Å omtale pasienten som «i dårlig form» er relativt lite informativt og kan være et eksempel på en slik utfordring. De (7) utviklet et eget triage-system (hastegradsvurdering) som skulle gi sykepleiere og leger et felles språk for å unngå tilbakemeldinger som «i dårlig form». 
God kommunikasjon mellom leger og sykepleiere mener vi er essensielt for å identifisere sepsis og kan trolig bidra til at behandlingen starter tidligere. Flere studier viser at flere avdelinger implementerte egne verktøy for å identifisere sepsis (7-9, 11). Det kan tolkes som at eksisterende verktøy er for lite spesifikke, og at flere har bedre nytte av kartleggingsskjemaer tilpasset deres arbeidsplass.

\section{三 «God kommunikasjon mellom leger og sykepleiere mener vi er essensielt for å identifisere sepsis.»}

Vi tror likevel det burde være et mål å utvikle felles retningslinjer for å identifisere sepsis. Vi kan også stille oss kritisk til om det vil fungere optimalt i praksis, og det må vurderes om et verktøy vil ha samme overføringsverdi på en intensivavdeling som på en sengepost. Det viktigste bør uansett være at alle som jobber på samme avdeling, har lik forståelse for hvordan kartleggingen skal praktiseres.

\section{Konklusjon}

Funnene i vår studie viste at økt kunnskap, klinisk kompetanse og bruk av kartleggingsverktøy bidrar til at sykepleiere tidligere kan identifisere sepsis på sengepost. Undervisning, simulering, klare retningslinjer og systematisk kartlegging bidrar til at sykepleiere får utnyttet sin gode posisjon overfor pasientene, slik at sykepleierne kan identifisere sepsis på et tidlig tidspunkt.

\section{Referanser}

1. Rygh M, Andreassen GT, Fjellet AL, Wilhelmsen IL, Stubberud DG. Sykepleie ved infeksjonssykdommer. I: Stubberud DG, Grønseth R, Almås H, red. Klinisk sykepleie bind 1. Oslo:

Gyldendal Akademisk; 2017. s. 69-117. 
2. Singer M, Deutschman CS, Seymour CW, Shankar-Hari M, Annane D, Bauer M, et al. The third international consensus definitions for sepsis and septic shock (Sepsis-3). JAMA. 2016;315(8):801-8.

3. Finfer S, Machado FR. The global epidemiology of sepsis. Does it matter that we know so little? Am J Respir Crit Care Med. 2016;193(3):228-30.

4. Nortvedt P, Grønseth R. Klinisk sykepleie funksjon, ansvar og kompetanse. I: Stubberud DG, Grønseth R, Almås H, red. Klinisk sykepleie bind 1. Oslo: Gyldendal Akademisk; 2017. s. 17- 40.

5. Evans D. Systematic reviews of interpretive research: Interpretive data synthesis of processed data. Aust J Adv Nurs. 2002-2003;20(2):22-6.

6. Delaney MM, Friedman MI, Dolansky MA, Fitzpatrick JJ. Impact of a sepsis educational program on nurse competence. J Contin Educ Nurs. 2015;46(4):179-86.

7. Torsvik M, Gustad LT, Mehl A, Bangstad IL, Vinje LJ, Damås JK, et al. Early identification of sepsis in hospital inpatients by ward nurses increases 30-day survival. Crit Care. 2016;20(1):244.

8. Tromp M, Hulscher M, Bleeker-Rovers C, Peters L, van den Berg TNA, Borm G, et al. The role of nurses in the recognition and treatment of patients with sepsis in the emergency department: A prospective before and-after intervention study. Int $\mathrm{J}$ Nurs Stud. 2010;47(12):1464-73.

9. Burney M, Underwood J, McEvoy S, Nelson G, Dzierba A, Kauari V, et al. Early detection and treatment of severe sepsis in the emergency departments: Identifying barriers to implementation of a protocol-based approach. J Emerg Nurs. 2012;38(6):512-7. 
10. Hengel LC, Visseren T, Meima-Cramer PE, Rood PP, Schult S. Knowledge about systemic inflammatory response syndrome and sepsis: a survey among Dutch emergency department nurses. Int J Hosp Med. 2016;9(19):1-7.

11. Gyang E, Shieh L, Forsey L, Maggio P. A nurse driven screening tool for the early identification of sepsis in an intermediate care unit setting. J Hosp Med. 2015;10(2):97-103.

12. Churpek MM, Snyder A, Han X, Sokol S, Pettit N, Howell MD, et al. Quick sepsis- related organ failure assessment, systemic inflammatory response syndrome, and early warning scores for detecting clinical deterioration in infected patients outside the intensive care unit. AJRCCM. 2017;195(7):906-11.

13. Churpek MM, Zadravecz FJ, Winslow C, Howell MD, Edelson DP. Incidence and prognostic value of the systemic inflammatory response syndrome and organ dysfunctions in ward patients. AJRCCM. 2015;192(8):958-64.

14. Kristoffersen NJ. Sykepleie kunnskapsgrunnlag og kompetanseutvikling. I:

Kristoffersen NJ, Nortvedt F, Skaug EA, Grimsbø GH, red. Grunnleggende sykepleie bind 1. Sykepleie - fag og funksjon. Oslo: Gyldendal Akademisk; 2016. s. 139-92.

15. Andreassen GT, Fjellet AL, Wilhelmsen IL, Stubberud DG. Sykepleie ved infeksjonssykdommer. I: Almås H, Stubberud DG, Grønseth R, red. Klinisk sykepleie bind 1. Oslo: Gyldendal Akademisk; 2015. s. 61-105.

16. Lov 2. juli $1999 \mathrm{nr} .64$ om helsepersonell (helsepersonelloven). Tilgjengelig fra: https://lovdata.no/dokument/NL/lov/1999-07-02-64 (nedlastet 14.01.2019). 
17. Kristoffersen NJ. Helse og sykdom. I:

Kristoffersen NJ, Nortvedt F, Skaug EA, red.

Grunnleggende sykepleie bind 1 . Sykepleiens

grunnlag, rolle og ansvar. Oslo: Gyldendal Akademisk;

2015. s. 31-81. 